\title{
Edukasi Pentingnya Vaksin Covid-19 Di Masa Pandemi pada Masyarakat di Kelurahan Baruga dan Watubangga Kota Kendari
}

\author{
${ }^{1}$ La Ode Muhamad Sety, ${ }^{2}$ Hariati Lestari, ${ }^{3}$ Putu Eka Meiyana Erawan \\ ${ }^{1}$ Fakultas Kesehatan Masyarakat, Universitas Halu Oleo, Kota Kendari \\ Korespondeni: setyuho@gmail.com
}

\begin{abstract}
Covid-19 is still a public health problem in the world, causing more than five million deaths. Indonesia is one of the countries that has quite a large number of Covid-19 cases, namely more than four million confirmed cases with one hundred and four thousand deaths. One of the efforts that have been made by the government in the context of preventing and controlling the disease is vaccination. However, even though the program is very good, not all people have accepted the COVID-19 vaccination program. This situation was also experienced at partner locations where in the preliminary survey, the results obtained were that public knowledge and awareness of the COVID-19 vaccine was still low. The participants were 50 posyandu cadres consisting of 25 people from Baruga Village and 25 people from Watubangga. The dedication method used is a lecture that begins with a pre-test, then counseling is carried out and ends with an evaluation using a post-test. The results of the evaluation showed an increase in knowledge after education about the benefits of the COVID-19 vaccine was carried out. The community and the head of the village agreed to help the government increase the coverage of the vaccine, which will start from the posyandu they have fostered.

Keywords :Education, Vaccines, Covid-19, Pandemic, Urban village.

Abstrak: Covid-19 hingga kini masih menjadi masalah kesehatan masyarakat di dunia, menyebabkan lebih dari lima juta kematian. Indonesia merupakan salah satu negara yang memiliki kasus Covid-19 cukup besar yakni lebih dari empat juta kasus konfirmasi dengan seratus empat tiga ribu kematian. Salah satu upaya yang telah dilakukan oleh pemerintah dalam rangka pencegahan dan pengendalian penyakit tersebut yaitu dengan vaksinasi. Namun demikian, meskipun program tersebut sangat baik, belum semua masyarakat menerima program vaksinasi Covid-19 tersebut. Keadaan ini juga dialami pada lokasi mitra dimana pada survey pendahulan, diperoleh hasil masih rendahnya pengetahuan dan kesadaran masyarakat terkait vaksin Covid-19. Partisipan sebanyak 50 orang kader posyandu terdiri dari 25 orang berasal dari Kelurahan Baruga dan 25 orang dari Watubangga. Metode pengabdian yang digunakan adalah ceramah yang diawali dengan pre tes, selanjutnya dilakukan penyuluhan dan diakhiri dengan evaluasi menggunakan post tes. Hasil evaluasi menunjukkan terjadi peningkatan pengetahuan setelah dilakukan edukasi perihal manfaat vaksin Covid-19. Masyarakat beserta kepala kelurahan bersepakat untuk membantu pemerintah meningkatkan cakupan vaksin yang akan diawali dari posyandu binaan mereka.
\end{abstract}

Kata Kunci :Edukasi,Vaksin, Covid-19, Pandemi, Kelurahan.

\section{PENDAHULUAN}

Corona Virus Disease (Covid-19) masih menjadi masalah kesehatan utama masyarakat di seluruh dunia menyebabkan lebih dari lima juta kematian, sedangkan Indonesia lebih dari empat juta kasus konfirmasi dengan seratus empat tiga ribu kematian ${ }^{1}$. Provinsi Sulawesi Tenggara di konfirmasi 17 Kabupaten yaitu 10.259 Positif, dengan 205 kematian², sedangkan Kota Kendari terdapat 4.586 kasus, sembuh 4.503, meninggal 59 per tanggal 30 Maret 2021. Kasus terbanyak terdapat di Kecamatan Baruga dengan jumlah kasus mulai tanggal 19 Juni 2020 sebanyak 2 orang Positif hingga pada tanggal 17 November di konfirmasi sebanyak 203 orang. Terdapat dua wilayah yang tercatat sebagai zona merah di Kecamatan Baruga yakni Kelurahan Baruga dan Watubangga ${ }^{3}$

Berdasarkan data kewaspadaan Covid-19 Kota Kendari senin 14 september 2020, Total keseluruhan kasus terkonfirmasi positif sebanyak 737 orang, sembuh 390 orang, meninggal 18 orang, 
dan masih dalam perawatan, isolasi atau karantina di rumah sakit sebanyak 329 orang. Sementara yang memiliki kontak erat sebanyak 1939 orang, selesai pemantauan 1204 orang dan masih dalam pemantauan kontak erat 735 orang. Untuk suspek total keseluruhan sebanyak 236 orang. Di Kecamatan Baruga, terdapat tiga kelurahan zona merah yakni Kelurahan Baruga, Watubangga dan Wundudopi serta Zona Kuning yakni Kelurahan Lepo-Lepo ${ }^{4}$.

Kecamatan Baruga merupakan kecamatan yang memiliki 4 Kelurahan yaitu Baruga, Lepo - lepo, Watubangga, Wundudopi yang memiliki luas daerah terbesar di Kota Kendari yaitu $48.00 \mathrm{~km}^{2}$ dengan jumlah penduduk 24.762 orang. Penduduk terbanyak terdapat di Kelurahan Baruga sebanyak 9.538 orang $^{5}$. Kepadatan penduduk merupakan jumlah penduduk yang menetap di suatu wilayah per satuan luas wilayah (ha). Semakin padat suatu wilayah, maka potensi penyebaran penyakit semakin besar. Kepadatan penduduk juga mempengaruhi sirkulasi udara dalam lingkungan yang berpotensi terhadap kontaminasi dari luar yang dapat meningkatkan risiko dan intensitas infeksi yang dapat memudahkan transmisi suatupenyakit'

Banyak upaya yang telah dilakukan oleh pemerintah dalam rangka pencegahan dan pengendalian Covid-19. Salah satu diantaranya adalah vaksinasi atau imunisasi yang tertuang dalam Perpres No. 99 tahun 2020 tentang pengadaan vaksin dan pelaksanaan vaksinasi dalam rangka Penanggulangan pandemi Covid-19 dan Permenkes No.84 tahun 2020 tentang pelaksanaan vaksinasi dalam rangka penanggulangan pandemi Covid-19. Program imunisasi merupakan salah satu upaya pelayanan kesehatan yang bertujuan untuk menurunkan angka kesakitan, kecacatan dan kematian dari penyakit, dan dapat meningkatkan kekebalan secara aktif terhadap suatu penyakit. Tujuan jangka pendek diberikannya imunisasi yaitu pencegahan penyakit secara perorangan dan kelompok sedangkan tujuan jangka panjangnya adalah eliminasi suatu penyakit?

Dari beberapa vaksin baik di negara-negara di dunia maupun di Indonesia, telah muncul keresahaan-keresahan masyarakat. Bagi masyarakat awam dengan informasi yang diperoleh baik melalui pendengaran dan penglihatannya tentu pasti memengaruhi persepsinya terhadap vaksin Covid-19. Persepsi manusia akan memengaruhi sikapnya nanti terhadap vaksin itu sendiri, yang pada akhirnya akan memengaruhi perilaku masyarakat terhadap vaksin. Hal ini mengandung makna bahwa ketika seseorang mempunyai persepsi yang kurang baik terhadap vaksinasi dari vaksin yang sudah teruji nantinya, maka jelas akan terjadi penolakan terhadap vaksinasi untuk perlindungan terhadap SARS-Cov.2. Dengan demikian, program untuk perlindungan dan pengendalian terhadap Covid-19 akan gagal, khususnya di wilayah-wilayah zona merah termasuk di Kota Kendari, Provinsi Sulawesi Tenggara.

Dengan demikian, penting untuk memberikan informasi yang tepat terhadap masyarakat tentang vaksin Covid-19. Berbagai kampanye sudah dilakukan oleh pemerintah melalui berbagai media seperti televisi, radio, seminar dan media sosial. Kampanye yang dilakukan oleh pemerintah kepada masyarakat lebih banyak yang satu arah yaitu dengan pendekatan komunikasi publik. Di mana komunikasi public ini interaksi antara penyampai pesan yaitu pemerintah dengan penerima pesan yakni masyarakat cenderung kurang atau terbatas ${ }^{7}$. Dalam hal ini, masyarakat diperlakukan sebagai objek suatu program. Beberapa studi sudah menjelaskan bahwa ketika masyarakat hanya dijadikan sebagai objek dari program pembangunan, maka keberhasilan program tersebut cenderung kurang efektif. Masyarakat haruslah menjadi subjek atau pelaku dalam setiap program termasuk dalam memberikan informasi tentang vaksin Covid-19 dan segala aspek tentang strategi perlindungan terhadap bahaya transmisi Covid-19. ${ }^{8}$

Kasus terbanyak untuk kota Kendari terdapat di Kecamatan Baruga yang merupakan wilayah kerja dari Puskesmas Lepo-Lepo dengan jumlah kasus mulai tanggal 19 Juni 2020 sebanyak 2 orang

This is an open-access article under the CC BY 4.0 International License (C) Idea Pengabdian Masyarakat (2022)

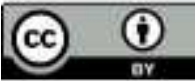


Positif hingga pada tanggal 17 November di konfirmasi sebanyak 203 orang. Di Kecamatan Baruga terdapat zona merah (Kelurahan Baruga, Kelurahan Watubangga Kelurahan Wundudopi) dan zona kuning (Kelurahan Lepo-Lepo). Di Kecamatan Baruga juga dilakukan program vaksinasi Covid-19, tetapi program ini memiliki beberapa kendala dan hambatan. Salah satu diantaranya adalah persepsi dan keresahan masyarakat awam menimbulkan pro dan kontra terhadap vaksin Covid-19.

Berdasarkan penelitian Tasnim tentang persepsi masyarakat tentang vaksin Covid-19 di wilayah Provinsi Sulawesi Tenggara menunjukan dari 210 responden, hanya14,3\% individu yang memliki persepsi baik terhadap vaksin Covid-19 dan masih terdapat 33,8\% yang kurang bersedia di vaksin ${ }^{9}$ Permasalahan utama yang dihadapi oleh mitra adalah masih rendahnya pengetahuan dan kesadaran terkait vaksin Covid-19, sehingga penting untuk memberikan informasi yang tepat terhadap masyarakat tentang vaksin Covid-19 di Kecamatan Baruga sebagai wilayah terbanyak kasus Covid 19 untuk Kota Kendari khususnya di 2 kelurahan terpadat penduduknya yaitu Kelurahan Baruga dan Watubangga yang berada pada wilayah kerja Puskesmas Lepo-Lepo.

\section{METODE}

Metode pelaksanaan kegiatan pengabdian terdiri dari beberapa tahap, pertama persiapan berupa koordinasi dengan mitra, penyusunan materi, pembuatan poster, leaflet dan koordinasi waktu pelaksanaan dengan mitra), kedua tahap pelaksanaan yakni pre test, pembagian poster, leaflet kepada peserta pelaksanaan penyuluhanan, ketiga tahap evaluasi dengan melakukan post tes

\section{HASIL DAN PEMBAHASAN}

Tahap persiapan

Persiapan diawali dengan Koordinasi dengan mitra terdiri dari Puskesmas Baruga sebagai unit Kesehatan di tingkat kecamatan serta kelurahan Baruga dan Watubangga yang menjadi sasaran kegiatan. Sasaran yang diikutkan pada kegiatan ini adalah kader posyandu berjumlah 100 orang. Poster dan leaflet disesuaikan dengan tingkat penerimaan partisipan. Kedua mitra tersebut sangat mendukung rencana pelaksanaan kegiatan dalam upaya optimalisasi kebijakan pemerintah dalam penanggulangan Covid 19 dalam bentuk penyuluhan kepada masyarakat. Pemerintah setempat berharap dengan kegiatan ini pengetahuan masyarakat menjadi lebih baik dalam memahami pentingnya vaksin dalam penanggulangan pandemic Covid 19.

\section{Tahap pelaksanaan}

Pelaksanaan kegiatan dilakukan dalam 2 gelombang yakni 4 Oktober 2011 berlokasi di Kelurahan Baruga dengan jumlah peserta 50 orang dan tanggal 18 Oktober 2011 di Kelurahan Watubangga dengan jumlah peserta juga 50 orang. Kegiatan diawali sambutan oleh kepala Puskesmas Baruga dan lurah setempat diselingi pembagian poster dan leaflet kepada peserta, kemudian di lakukanpre test. Selanjutnya kami lakukan penyuluhan perihal pentingnya vaksind alam mencegah penyakit Covid-19. Kegiatan ini juga melibatkan 5 orang mahasiswa Kesehatan masyarakat sebagai bentuk pembelajaran lapangan guna menambah wawasan dan mengasah keilmuan dilapangan.

Peserta kegiatan umumnya adalah ibu- ibu yakni 94\% dari 100 peserta. Mereka umumnya adalah kader posyandu. Diskusi yang aktif umumnya menyangkut jenis, efek samping, hingga efektivitas vaksin.

Tahap evaluasi 
Secara umum terjadi penambahan tingkat pengetahuan peserta perihal vaksin Covid-19 setelah dilakukan penyuluhan. Rata-rata skor pengetahuan sebelum 74 dan setelah penyuluhan terjadi peningkatan rata-rata 86.

Tabel 1 Indikator Ketercapaian Kegiatan

\begin{tabular}{lll}
\hline No & \multicolumn{1}{c}{ Indikator Kegiatan } & \multicolumn{1}{c}{ Keterangan } \\
\hline 1 & Penyuluhan Vaksinasi Covid-19 & Terlaksana \\
\hline 2 & Pembagian poster dan leaflet & Terlaksana \\
\hline 3 & Meningkatnya pengetahuan masyarakat tentang vaksin & Tercapai
\end{tabular}

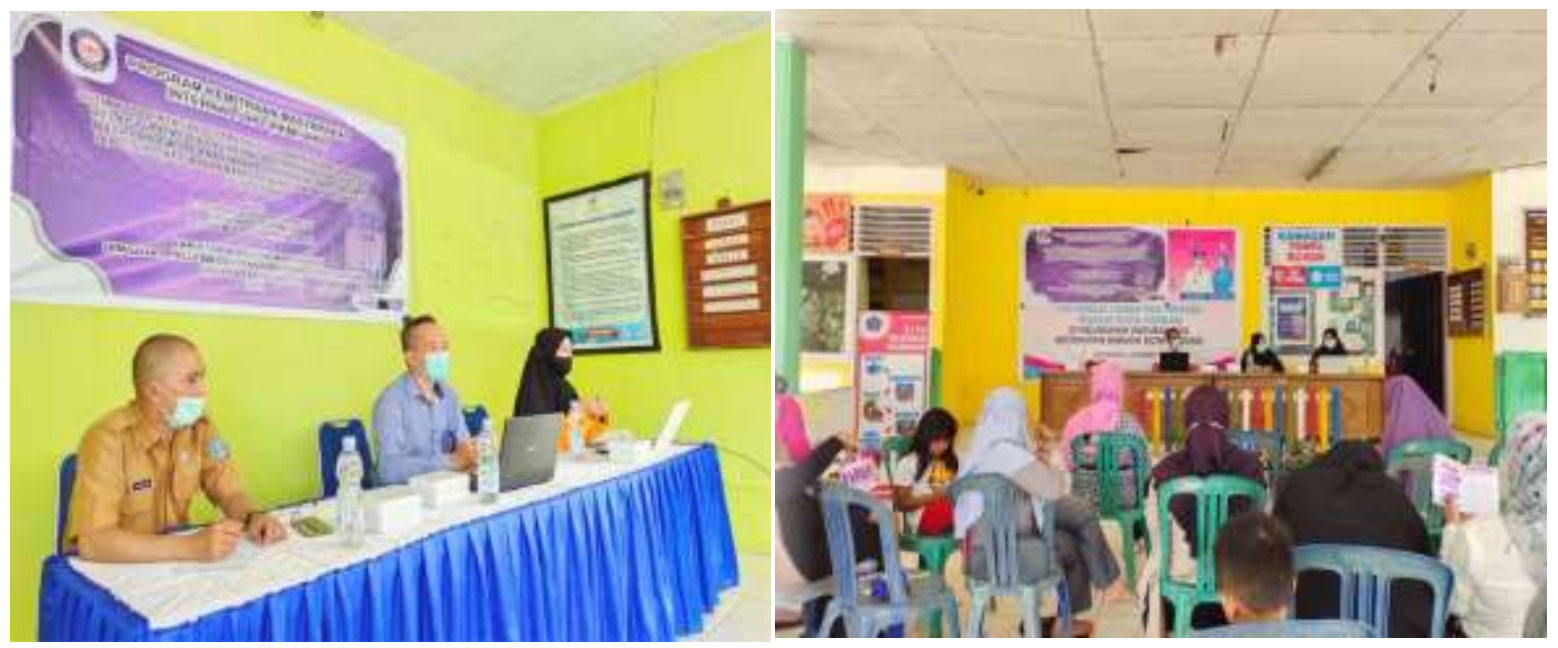

Gambar 1 \& 2 : KegaiatanPenyuluhandi KelurahanBaruga dan Watubangga

Hasil temuan pada pengabdian ini sejalan dengan temuan Aldilawati (2021) perihal edukasi vakasinasi Covid-19 dan penerapan 5 M dalam menanggulangi penularan Covid-19 di Desa Borisallo Kabupaten Gowa dimana terdapat peningkatan pengetahuan setelah edukasi ${ }^{10}$. Hal serupa juga ditemukan Safitri, (2021) perihal Penyuluhan pentingnya pemberian imunisasi terhadap anak di Desa Pasar VI Kualanamu ${ }^{11}$, serta Bomboa et al., (2015) menunjukkan bahwa peserta penyuluhan memperoleh pemahaman pengetahuan tentang imunisasi yang lebih baik dibandingkan sebelum penyuluhan serta perubahan sikap peserta menjadi lebih baik sudah mulai terlihat di akhir acara penyuluhan pada saat melakukan evaluasi sikap secara lisan kepada peserta penyuluhan, dengan begitu akan merubah pandangan peserta menjadi lebih peduli dan mendukung kegiatan imunisasi. Dapat disimpulkan bahwa dengan pemberian dengan penyuluhan kesehatan yang efektif dapat mempengaruhi pengetahuan dan sikap seseorang ${ }^{12}$.

Melihat begitu berbahayanya dampak yang ditimbulkan oleh Covid-19, hampir setiap negara di dunia termasuk Indonesia mengambil langkah-langkah preventif berupa pembatasan sosial, pengaturan jarak fisik, serta karantina wilayah baik dalam skala penuh maupun terbatas serta mencari vaksin yang tepat sebagi pencegahan?. 
Imunisasi telah diakui sebagai upaya pencegahan suatu penyakit infeksi yang paling sempurna dan berdampak pada peningkatan kesehatan masyarakat ${ }^{11}$. Peraturan Presiden Nomor 99 Tahun 2020 tentang Pengadaan Vaksin dan Pelaksanaan Vaksinasi Dalam Rangka Penanggulangan Pandemi Corona Virus Disease 2019 (COVID-19 19) (Lembaran Negara Republik Indonesia Tahun 2020 Nomor 227) sebagaimana telah diubah dengan Peraturan Presiden Nomor 14 Tahun 2021 tentang Perubahan Atas Peraturan Presiden Nomor 99 Tahun 2020 tentang Pengadaan Vaksin dan Pelaksanaan Vaksinasi Dalam Rangka Penanggulangan Pandemi Corona Virus Disease $2019^{13}$.

Vaksinasi ditujukan untuk melindungi tubuh dan memberikan kekebalan (herd imunity) untuk menangkal virus Covid-19. Vaksin diberikan oleh Pemerintah secara gratis dengan harapan semua masyarakat terpenuhi untuk vaksin ${ }^{8}$. Pada masa pandemic ini ada banyak presepsi masyarakat terhadap vaksin Covid-19 oleh karena itu diperlukan suatu kegiatan penyuluhan tentang pentingnya imunisasi dimasa pandemic dalam rangka penanggulangan pandemi Covid-19. Penyuluhan merupakan suatu media komunikasi yang dapat digunakan untuk menyampaikan informasi tentang pentingnya imunisasi. 14

Peningkatan pengetahuan masyarakat sesudah diberikan penyuluhan tentang pentingnya imunisasi di masa pandemic merupakan strategi untuk meningkatan cakupan vaksinasi Covid-19 dalam upaya herd immunity. Pengetahuan adalah salah satu hal yang penting diperhatikan dalam rangka penanganan kasus Covid-19. Pengetahuan masyarakat khususnya dalam mencegah transmisi penyebaran virus SARS-CoV-2 sangat berguna dalam menekan penularan virus tersebut ${ }^{15}$.

\section{KESIMPULAN}

Edukasi pentingnya vaksinasi Covid-19 dengan penyuluhan secara interaktif dengan poster dan leaflet mampu meingkatkan pengetahuan masyarakat dalam upaya pencegahan terhadap Covid- 19 . Keterlibatan tokoh masyarakat khususnya kaderposyandu diharapkan dapat meningkatkan optimalisai kebijakan pemerintah meningkatkan cakupan vaksinasi Covid-19 di Indonesia.

\section{UCAPAN TERIMAKASIH}

Kami mengucapkan terima kasih kepada Kepala Puskesmas Baruga, Lurah Baruga dan Watubangga, kader, tokoh masyarakat, serta mahasiswa yang terlibat dan mendukung terlaksananya kegiatan pengabdian masyarakat ini.

\section{DAFTAR PUSTAKA}

1. WHO. WHO Corona Virus (COVID-19) Dashboard2021:[1-6 pp.].

2. Fauzany C. Data Covid-19 di Sultra 30 Maret 2021 Accessed 1 Dec 2021. Available from: https://sultra.tribunnews.com/2021/03/30/data-Covid-19-di-sultra-per-selasa-30-maret-2021.

3. SatgasCovid-19_Sultra. Monitoring data Covid-19 Sultra 2021 Accessed 21 Oktober 2021. Available from: https://corona.sultraprov.go.id/.

4. Kendari DK. Release data medis Covid-19 Kota Kendari 14 September 202020201 Desember 2020. Available from: https://www.youtube.com/watch?v=C3MXyRrGLhg.

5. BPS_Kota_Kendari. Kota Kendari dalam Angka 2021. Kendari: BPS Kota Kendari; 2021. Available from: https://kendarikota.bps.go.id/publication/2021/02/26/1169f78ff9fe8182c8057b0d/kotakendari-dalam-angka-2021.html. 
6. Gapar IGS, Putra NA, Pujaastawa I. Hubungan kualitas sanitasi rumah dengan kejadian penyakit infeksi saluran pernapasan akut (ISPA) di wilayah kerja Puskesmas IV Denpasar Selatan Kota Denpasar. Ecotrophic. 2015;9(2):41-5.

7. Nasution DAD, Erlina E, Muda I. Dampak pandemi Covid-19 terhadap perekonomian Indonesia. Jurnal Benefita. 2020;5(2):212-24.

8. Noprianty R, Asnawi A, Jundiah J, Widyastuti L. Peningkatan Pengetahuan Siswa terhadap Vaksinasi Covid-19 melalui Edukasi di SMK Bhakti Kencana Tasikmalaya. Jurnal Peduli Masyarakat. 2021;3(3):251-6.

9. Suherman A, Tetep T, Supriyatna A, Mulyana E, Widyanti T, Saripah O, et al. Persepsi Masyarakat Terhadap Pemberlakuan Social Distancing Di Masa Pandemi Covid-19 Sebagai Implementasi Modal Sosial. Business Innovation and Entrepreneurship Journal. 2021;3(1):25-31.

10. Aldilawati S, Hidayat R. Edukasi Vaksinasi Covid-19 dan Penerapan 5M Dalam Menanggulangi Penularan Covid-19 di Desa Borisallo Kabupaten Gowa. Idea Pengabdian Masyarakat. 2021;1(02):59-63.

11. Safitri R. Penyuluhan Tentang Pentingnya Pemberian Imunisasi Terhadap Anak di Desa Pasar VI Kualanamu. Jurnal Abdidas. 2021;2(2):370-4.

12. Bomboa VF, Pascoal ME, Lumy F. Pengaruh penyuluhan imunisasi campak terhadap peningkatan pengetahuan dan sikap ibu. JIDAN (Jurnal Ilmiah Bidan). 2015;3(2):45-50.

13. RI KK. Petunjuk Teknis Pelaksanaan Vaksinasi dalam Rangka Penanggulangan Pandemi Corona Virus Disease 2019 (Covid-19)20201 Desember 2021. Available from: https://persi.or.id > wpcontent > uploads > 2021/07.

14. Notoatmodjo S. Ilmu Perilaku Kesehatan. Jakarta: Rineka Cipta; 2014.

15. Law S, Leung AW, Xu C. Is the traditional Chinese herb "Artemisia annua" possible to fight against COVID-19? Integrative Medicine Research. 2020;9(3). 